Orthopäde $2019 \cdot 48: 426-432$ https://doi.org/10.1007/s00132-018-3640-6 Published online: 20 September 2018 (c) The Author(s) 2018

CrossMark

Wanyi Wang' · Tao Ding' · James S. Harrop ${ }^{2} \cdot$ Huilin Yang ${ }^{3} \cdot$ Xiaofeng Gu' · Dehong Feng ${ }^{1}$ - Yafeng Zhang ${ }^{4} \cdot \mathrm{Hao} \mathrm{Liu}^{5} \cdot$ Fenglin Tang ${ }^{1}$ - Yuntao Xue ${ }^{1} \cdot$ Miao Lu' . $\mathrm{Chao} \mathrm{Wu}^{6}$

'Department of Orthopaedics, Wuxi People's Hospital Afflicted to Nanjing Medical University, Wuxi, China ${ }^{2}$ Departments of Neurological and Orthopedic Surgery, Thomas Jefferson University Hospital, Philadelphia, USA

${ }^{3}$ Department of Orthopedic Surgery, The First Affiliated Hospital of Soochow University, Suzhou, China ${ }^{4}$ Department of Orthopaedics, Wuxi Affiliated Hospital of Nanjing University of Chinese Medicine, Wuxi, China

${ }^{5}$ Department of Orthopaedics, Wuxi 9th People Hospital, Wuxi, China

${ }^{6}$ Wuxi 3th People Hospital, Wuxi, China

\title{
Cervical posterior longitudinal ligament ossification
}

\section{Microscopy-assisted anterior corpectomy and fusion}

approaches to the goal of spinal cord decompression include anterior, posterior and combined anteroposterior approaches. Anterior cervical corpectomy can be employed when the compression is along the posterior vertebral body and a cervical discectomy alone will not provide adequate spinal decompression for OPLL. Advantages of anterior procedures include reduced surgical invasion, decreased blood loss and lower risk of neurological decline [5]. Microscopyassisted anterior cervical decompression is considered to be an effective surgical option [6].

\section{Material and methods}

A total of 32 patients treated with microscopically enhanced ACC were retrospectively studied and followed up for 3 months to 1 year to assess the safety and efficacy of this process.

\section{Patient population and preoperative evaluation}

A total of 32 cases were included from June 2012 to March 2017 including 15 males and 17 females. The age range was $42-68$ years (average $58.3 \pm 2.9$ years) and the mean duration of follow-up was
11-46 months (19.0 \pm 3.5 months). The main presenting symptoms were neck and shoulder pain, numbness of the upper extremities, difficulty in holding objects, weakness in the lower extremities, gait dysfunction and abnormal lower extremity sensation.

\section{Inclusion, classification and exclusion criteria}

Exclusion criteria were ossification of the ligamentum flavum and intramedullary space occupying lesions. The OPLL classification was according to the OPLL criteria of Tsuyama and there were 10 cases

\begin{tabular}{|ll}
\hline \multicolumn{2}{|l}{ Abbreviations } \\
\hline$A C C$ & Anterior cervical corpectomy \\
\hline$C S F$ & Cerebrospinal fluid \\
\hline$C T$ & Computed tomography \\
\hline$D O$ & Dural ossification \\
\hline JOA & Japanese Orthopaedic Association \\
\hline$M R I$ & Magnetic resonance imaging \\
\hline$O P L L$ & $\begin{array}{l}\text { Ossification of posterior longitudi- } \\
\text { nal ligament }\end{array}$ \\
\hline$O R$ & Occupying rate \\
\hline VAS & Visual analog scale \\
\hline
\end{tabular}



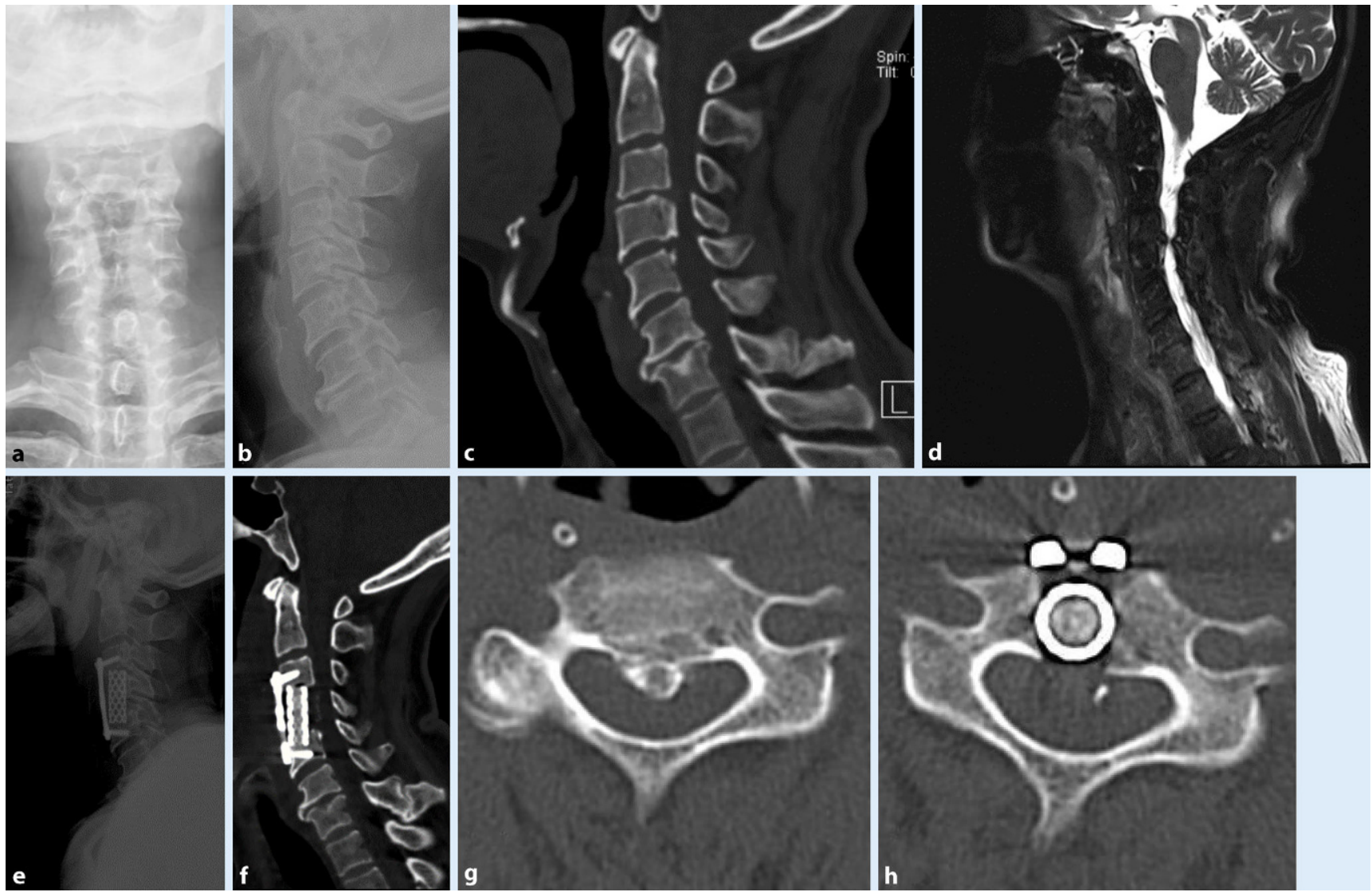

Fig. 1 A A 67-year-old male with C4-C6 mixed type OPLL associated with dural ossification. a, b Preoperative orthographic and sagittal radiographic image at neutral position. c Preoperative sagittal CT scans demonstrating a C4-C6 mixed type OPLL with double layer sign. $\mathbf{d}$ Preoperative MRI shows severe compression of the spinal cord. e Postoperative radiographic image showing $\mathrm{C} 5$ corpectomy and fusion. $\mathbf{f}$ Postoperative sagittal CT demonstrating the internal fixator is in place. $\mathbf{g}, \mathbf{h}$ Preoperative and postoperative axial CT demonstrating complete resection of OPLL and floating of Dural ossification (DO)

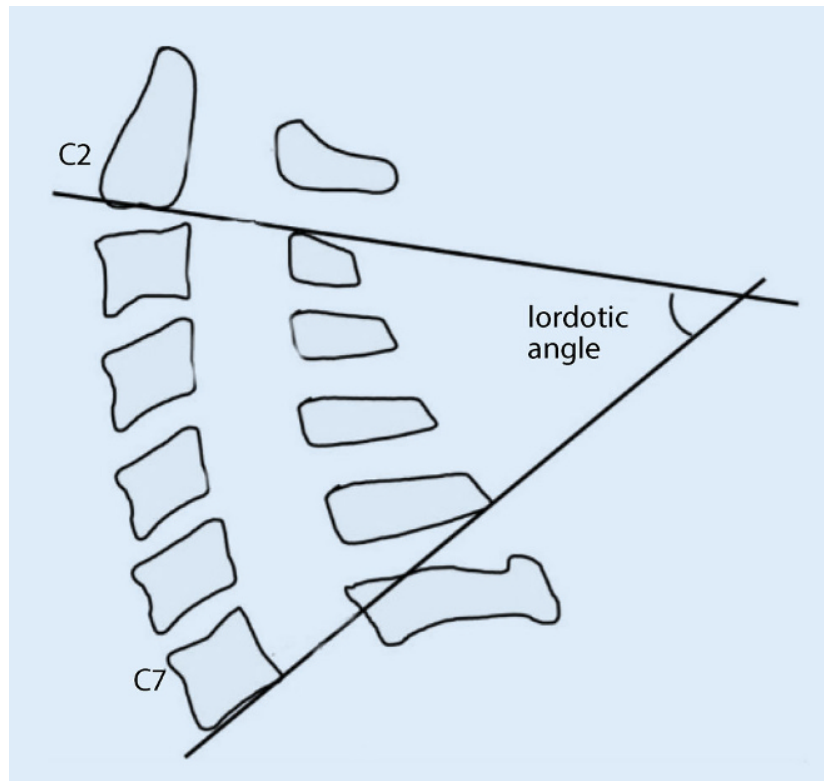

Fig. $2<$ Sketch showing how the lordotic angle was measured on lateral X-ray based on the line of the lower endplates of $\mathrm{C} 2$ and C7 of continuous type, 8 cases of segmental type, 10 cases of mixed type and 4 cases of localized type [7]. In 24 patients, the ossification of the posterior longitudinal ligament showed a strip or nodule on the lateral X-ray film. The CT scan showed that the ossification of the posterior longitudinal ligament had a thickness of the between 3.36 and $8.04 \mathrm{~mm}$ and the average was $5.87 \pm 1.12 \mathrm{~mm}$. The corresponding sagittal diameter of the spinal canal was $8.2-14.4 \mathrm{~mm}$ and the average was $11.24 \pm 2.24 \mathrm{~mm}$. The MRI examination showed spinal cord atrophy, with 14 cases of increased intramedullary signal intensity in T2-weighted MRI. The occupying rate (OR) was defined as the thickness of OPLL divided by the anteroposterior diameter of the bony spinal canal on the CT axial image and the rate was calculated to be $29.2-72.2 \%$ with an average of $51.36 \pm 11.89 \%$ (• Fig. 1 ). 
Orthopäde 2019 · 48:426-432 https://doi.org/10.1007/s00132-018-3640-6

(c) The Author(s) 2018

W. Wang · T. Ding · J. S. Harrop · H. Yang · X. Gu • D. Feng · Y. Zhang · H. Liu · F. Tang · Y. Xue · M. Lu · C. Wu

\section{Cervical posterior longitudinal ligament ossification. Microscopy-assisted anterior corpectomy and fusion}

\section{Abstract}

Objective. To explore the clinical efficacy and safety of microscopy-assisted anterior corpectomy and fusion for cervical ossification of the posterior longitudinal ligament (OPLL). Methods. A retrospective review of 32 cervical OPLL patients who underwent microscopyassisted anterior corpectomy and fusion from June 2012 to March 2017 was carried out. Patients were evaluated with outcome metrics: Japanese Orthopaedic Association (JOA) scores (17 points method), visual analog scale (VAS), and radiographic parameters of the lordotic angle. The complications during treatment and follow-up were recorded.
Results. This study included 32 patients (15 males and 17 females) with a mean age of $58.3 \pm 2.9$ years (range $42-68$ years). The average duration of follow-up was $19.0 \pm 3.5$ months (range 11-46 months). The scores of postoperative VAS significantly decreased $(P<0.05)$. The average JOA score at 12 months postoperation significantly improved $(p<0.05)$. The lordotic angle increased after surgery $(P<0.05)$. There was no titanium mesh subsidence, no pseudarthrosis or hardware failure at 1-year follow-up. Complications: One cerebrospinal fluid leakage in the surgery was managed using a gelatine sponge and the patient recovered after 1 week: One patient developed laryngeal nerve injury symptom of hoarseness and recovered spontaneously in 2 weeks without intervention and 1 patient suffered slight postoperative infection. There was no worsening of neurological function. Conclusion. Microscopy-assisted anterior cervical anterior surgery appears to be a safe and effective treatment option for selected cases of cervical posterior longitudinal ligament ossification.

Keywords

Cervical vertebrae · Myelopathy · Decompression - Retrospective studies - Treatment outcome

\section{Ossifikation des zervikalen Lig. longitudinale posterius. Mikroskopisch gestützte vordere Korporektomie und Fusion}

\section{Zusammenfassung}

Ziel. Ziel der Studie war, die klinische Wirksamkeit und Sicherheit der mikroskopisch gestützten vorderen Korporektomie und Fusion bei Ossifikation des zervikalen Lig. longitudinale posterius (OPLL) zu ermitteln. Methoden. Es wurde eine retrospektive Übersichtsstudie mit 32 Patienten durchgeführt, die zwischen Juni 2012 und März 2017 bei zervikaler OPLL einer mikroskopisch gestützten vorderen Korporektomie und Fusion unterzogen worden waren. Die Patienten wurden anhand folgender Ergebnisparameter eingeschätzt: JapaneseOrthopaedic-Association(JOA)-Scores (17Punkte-Verfahren), visuelle Analogskala (VAS) und Röntgenparameter des Lordosewinkels. Komplikationen während der Behandlung und in der Nachsorge wurden dokumentiert.
Ergebnisse. Die Studie schloss 32 Patienten (15 männlich, 17 weiblich) in einem Durchschnittsalter von $58,3 \pm 2,9$ Jahren (Bereich 42-68 Jahre) ein. Die Follow-up-Dauer betrug 19,0 \pm 3,5 Monate (Bereich 11-46 Monate). Die VAS-Werte sanken postoperativ signifikant $(P<0,05)$. Der durchschnittliche JOA-Wert war 12 Monate nach Operation signifikant verbessert $(p<0,05)$. Der Lordosewinkel nahm nach der Operation zu $(P<0,05)$. Im 1-JahresFollow-up kam es nicht zu einer Sinterung des Titangitters, einer Pseudarthrose oder einem Materialversagen. Komplikationen: Ein Fall von Liquorverlust im Rahmen des operativen Eingriffs wurde mit einem Gelatineschwamm behandelt. Der Patient erholte sich nach einer Woche. Bei einem Patienten traten Symptome einer N.-laryngeus-Verletzung (Heiserkeit) auf, die innerhalb von 2 Wochen ohne Intervention spontan nachließen. Ein Patient erlitt eine leichte postoperative Infektion. Eine Verschlechterung des neurologischen Funktionsstatus war nicht zu verzeichnen. Schlussfolgerung. Die mikroskopisch assistierte anteriore zervikale Operation hat sich als sichere und wirksame Behandlungsoption bei ausgewählten Fällen einer Ossifikation des zervikalen Lig. longitudinale posterius erwiesen.

\section{Schlüsselwörter}

Halswirbel · Myelopathie - Dekompression · Retrospektive Studien · Behandlungsergebnis

\section{Surgical procedures}

Operations were performed via a standard right side anterior cervical approach. After caudal and rostral discectomies, the index vertebral body was partially removed using a rongeur. The residual underlying vertebral bodies and OPLL bone were thinned with a high speed burr. Microscopy facilitated drilling the OPLL to extremely thin over the dura. Then, the OPLL was separated from the dura mater using microdissector and removed with a 1-mm Kerrison laminectomy rongeur or left floating if solid adherents were present. The floating parts of OPLL was isolated, paper thin and separated all around from the vertebral body. The conservation of the adhered part of the OPLL has no effect on the re-expanded dura and avoids spinal fluid leakage or injury to the spinal cord. After decompression, a titanium mesh cage filled with autologous bone fragments and an anterior cervical plate were used to restore the stability of the involved segments. After the operation, patients were immobilized in a Philadelphia collar for at least 3 months [8].

\section{Observation indexes}

Operative time, blood loss, hospital stay, and postoperative complications such as CSF leakage, C5 palsy, neurological de- 
Hier steht eine Anzeige.

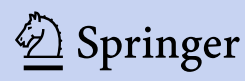




\section{Table 1 Patient characteristics}

\begin{tabular}{ll}
\hline Parameter & Number \\
\hline Gender & \\
Male & 15 \\
Female & 17 \\
\hline Age (years) & $58.3 \pm 2.9$ \\
\hline $\begin{array}{l}\text { Course of disease (months) } \\
\text { Preoperative JOA score }\end{array}$ & $19.0 \pm 3.5$ \\
\hline $\begin{array}{l}\text { Preoperative VAS score } \\
\text { Preoperative lordotic angle }\left(^{\circ} \text { ) }\right.\end{array}$ & $7.32 \pm 1.80$ \\
\hline $\begin{array}{l}\text { OPLL type } \\
\text { Localized type }\end{array}$ & 4 \\
\hline $\begin{array}{l}\text { Continuous type } \\
\text { Segmental type }\end{array}$ & 10 \\
\hline $\begin{array}{l}\text { Mixed type } \\
\text { Spinal stenosis rate (\%) }\end{array}$ & 8 \\
\hline $\begin{array}{l}\text { JOA Japanese Orthopaedic Association, } \\
\text { OPLL ossification of the posterior longitudi- } \\
\text { nal ligament, VAS visual analog scale }\end{array}$ \\
\hline
\end{tabular}

terioration, hoarseness, dysphagia, and instrumentation failure were recorded. Visual analogue scores (VAS) were used to assess pain. Analysis of the differences in preoperative and postoperative VAS was used to evaluate the patient's pain relief. The Japanese Orthopaedic Association (JOA) score was used to determine neurological improvement rate before and after surgery [9]. The improvement rate, which was calculated as (postoperative score-preoperative score $) /(17$-preoperative score $) \times 100 \%$, is divided into 4 levels: $\geq 75 \%$ is excellent, $50-74 \%$ is good, $25-49 \%$ is mild and $\leq 24 \%$ is poor. The rate of excellent surgery was the ratio of the number of patients in the excellent level to the total number of patients in this group [10,11]. In addition, anterior approach surgery is able to correct cervical lordosis so that neurological function is improved. In order to assess the correction of lordosis, the preoperative and postoperative cervical lordotic angle (• Fig. 2) was measured on lateral X-rays based on the line of the lower endplates of C2 and C7 [12].

\section{Statistical analysis}

A paired t-test was used to determine the difference in JOA score, VAS score, and lordotic angle before surgery and
Table 2 Surgical status of the patients in the study

\begin{tabular}{l|l} 
& Amount \\
\hline Operative time (min) & $158.2 \pm 20.9$ \\
\hline Intraoperative bleeding $(\mathrm{ml})$ & $80.5 \pm 10.2$ \\
\hline Average length of stay (days) & $6.5 \pm 1.8$
\end{tabular}

at the last follow-up. Logistic regression analysis was conducted to determine the factors correlating to clinical results. Analysis was performed using SPSS for Windows, Version 16.0 (SPSS, Chicago, IL, USA), and a $P$-value of less than 0.05 was considered significant.

\section{Results}

\section{Patient characteristics}

The preoperative clinical data including gender, age, duration of symptom, preoperative JOA score, VAS score, lordotic angle, spinal stenosis rate and type, are shown in $\bullet$ Table 1.

\section{Surgical status}

Operative time, intraoperative bleeding and average length of hospital stay are shown in $\bullet$ Table 2.

\section{Clinical and radiological outcomes}

The VAS score was used to assess pain relief. Postoperative scores (3.2 \pm 0.4 , $P<0.05)$ were significantly lower. The specific data are shown in - Table 3. Average score of JOA at 12 months after surgery was significantly increased $(15.76 \pm 1.05, p<0.05)$. The average improvement rate of neurological function was $83.85 \pm 12.05 \%$ (- Table 4 ). The lordotic angle was used to evaluate the curvature change of the cervical spine. The mean lordotic angle improved from $15.4 \pm 5.3^{\circ}$ preoperatively to $22.8 \pm 6.2^{\circ}$ postoperatively (• Table 5 ).

\section{Complications}

The duration of follow-up was $19.0 \pm 3.5$ months (range 11-46 months). There was no titanium mesh subsidence, pseudarthrosis or hardware failure. There was one case of intraoperative cerebrospinal fluid leakage and was managed with a gelatine sponge covered with gelatine gel. There were no obvious abnormalities observed at the 3 months and 1 year followups [13]; however, one patient developed hoarseness and difficulty in swallowing postoperatively and fully recovered at 1 month after surgery and one case had slight postoperative infection, which was limited to superficial tissue and recovered with antibiotic treatment.

\section{Discussion}

The OPLL of the cervical spine is an occult process and clinical and symptomatic progression is typically relatively slow at onset; however, it tends to be a continuous process of pathological development. In the early stage of the ossification, OPLL is generally asymptomatic or only mildly symptomatic. With the hypertrophy of the ligament tissue, the ossification lesion can enlarge longitudinally as well as extend into the spinal canal. As a result, cervical spinal stenosis and compression of the spinal cord may occur. In some patients, spinal cord function will be affected, resulting in deterioration of spinal cord function especially when encountering minor trauma. Most authors agree that the best time for surgical intervention is prior to irreversible spinal cord dysfunction but defining this time period is difficult. Operative treatment may interrupt the natural process of OPLL and prevent further deterioration of spinal cord function [14]. Spinal cord compression results in pathological clinical symptoms of cervical OPLL, which may be relieved with decompression. Because the spinal cord compression in patients with cervical OPLL is ventral to the spinal cord, the most direct surgical approach is an anterior resection of the intervertebral disc and hyperplastic bone callus, which directly decompresses the spinal cord, nerves and anterior spinal artery. The width and extent of decompression should cover the base of ossification to prevent residual fragments and recurrence of the ossification lesion.

The degree of spinal cord compression, cervical spine lordosis and involved segments affect the choice of surgical strategy. When the cervical disc herniation 


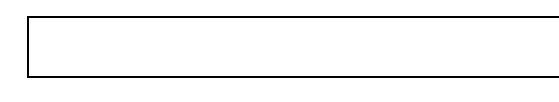

is located in the ossification section and the segment involved is less than three vertebral body lengths, in our experience an anterior surgery is often suitable. In contrast, posterior decompression is relatively more widely accepted by some surgeons, but the short-term and longterm effects of neurological decompression may not be as good as those of anterior surgery [15].

The improvement of lordosis in patients with OPLL can further improve neurological function. Therefore, intraoperative correction and postoperative maintenance of cervical lordosis curvature have a profound effect on the prognosis of OPLL. Anterior surgery is more effective in restoring lordosis than posterior surgery $[16,17]$. It has been reported that the neurological improvement at 1 week postoperation was less by the anterior approach, but with longer follow-up at 1 year and 5 years there was a significantly increased neurological function and JOA score compared to the posterior approach [18].

Microscopy-assisted spinal decompression has the following advantages for some surgeons: (1) improvement of the visible quality within the deep and narrow operation field, (2) facilitation of identification of the microstructure of the dural sac, nerve root, vascular plexus and ligament ossification and (3) improved microscopic hemostasis.

In summary, microscopy-assisted anterior cervical decompression appears to be a safe and effective surgical treatment for cervical OPLL; however, the current study still has several limitations to making a definitive conclusion. The sample size was too small and there was most likely an inherent patient selection bias. In addition, due to the lack of randomization or control of confounding factors, the overall conclusions are limited. Therefore, further clinical studies on surgical approaches with cervical OPLL and long-term follow-up would be beneficial.

\section{Conclusion}

In this retrospective study 32 cervical OPLL cases underwent microscopeassisted anterior corpectomy and fusion with evaluative criteria including

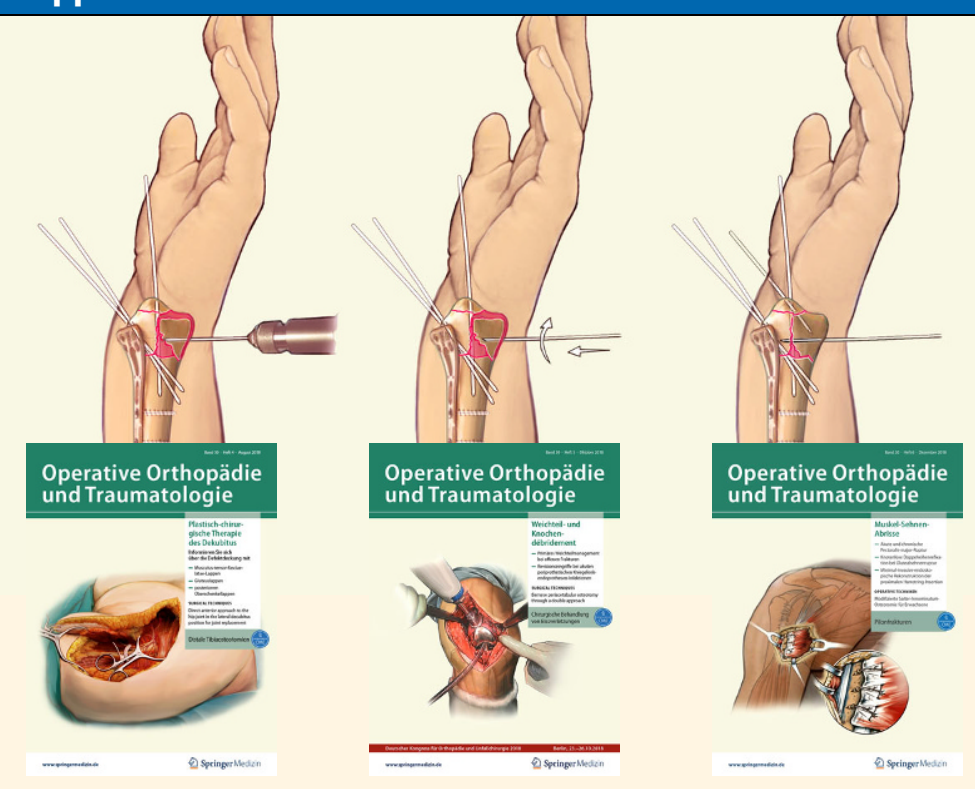

\section{Suchen Sie noch mehr zum Leitthema?}

Die Zeitschrift Operative Orthopädie und Traumatologie bietet Ihnen fundierte Informationen zu bewährten und neuen Operationstechniken der Orthopädie, Unfall-, Hand- und Wiederherstellungschirurgie. In den aufwendig illustrierten Beiträgen werden die Operationsverfahren Schritt für Schritt vorgestellt.

Passend zum Leitthema „Endoprothetik an Hand und Handgelenk“ in dieser Ausgabe können Sie sich in der OOT z.B. über folgende Operationstechniken informieren:

- Der Fingermittelgelenkersatz mit Pyrocarbonprothesen Meier R, Schulz M, Krimmer H et al. (2007) Orthop Traumatol 19:1-15

- Der palmare Zugang zur Arthroplastik des proximalen Interphalangeal-Finger-Gelenks Simmen BR (1993) Operat Orthop Traumatol 5:112-123

- Die Arthrodese des proximalen Interphalangealgelenkes in der Feder-Nut-(Peg-in-hole-) Technik

Wolke B, Sparmann M (1999) Operat Orthop Traumatol 11:319-327

- Operationen bei Sattelgelenkarthrose: Francobal $^{\circledR}{ }^{-}$Endoprothese nach de la Caffinière Helbig B (1989) Operat Orthop Traumatol 1:109-115

- Treatment of osteoarthritis of the first carpometacarpal joint by resection-suspension-interposition arthoplasty using the split abductor pollicis longus tendon Harenberg P, Jakubietz M, Jakubietz R et al. (2013) Oper Orthop Traumatol 25:95-103

- Die Arthrodese des Fingermittelgelenks mittels Zuggurtungsosteosynthese Hohendorff B, Franke J, Spies CK et al. (2017) Oper Orthop Traumatol 29:385-394

- Oberflächenersatz am Fingermittelgelenk mittels CapFlex-PIP Schindele SF, Altwegg A, Hensler S (2017) Oper Orthop Traumatol 29:86-96

Mit e.Med - den maßgeschneiderten Fortbildungsabos von Springer Medizin - haben Sie Zugriff auf alle Inhalte von SpringerMedizin.de. Sie können schnell und komfortabel in den Zeitschriften Ihres Fachgebietss recherchieren und auf alle Inhalte im Volltext zugreifen.

Weitere Infos zu e.Med finden Sie auf springermedizin.de unter "Abos" 
Table 3 Improvement of pain release. (12 months postoperatively)

\begin{tabular}{llllll} 
& Preoperative VAS & Postoperative VAS & T-value & $\boldsymbol{P}$-value \\
\hline Group & $7.9 \pm 1.4$ & $3.2 \pm 0.4$ & 18.2602 & $<0.05$
\end{tabular}

Table 4 Improvement of neurological functions

\begin{tabular}{|c|c|c|c|c|}
\hline Preoperative JOA & Postoperative JOA & $\begin{array}{l}\text { Improvement } \\
\text { rate (\%) }\end{array}$ & T-value & $P$-value \\
\hline $9.32 \pm 1.80$ & $15.76 \pm 1.05$ & $83.85 \pm 12.05$ & -17.4820 & $<0.05$ \\
\hline
\end{tabular}

Table 5 Change of curvature of the cervical spine

\begin{tabular}{|l|lll}
\hline Preoperative lordotic angle $\left({ }^{\circ}\right)$ & Postoperative lordotic angle $\left({ }^{\circ}\right)$ & T-value & $P$-value \\
\hline $15.4 \pm 5.3$ & $22.8 \pm 6.2$ & -5.1731 & $<0.05$
\end{tabular}

intraoperative bleeding, average hospitalization duration, VAS score, JOA score and the incidence of postoperative complications. The results suggest that microscopy-assisted anterior cervical surgery appears to be a safe and effective treatment option for selected cases of cervical OPLL.

\section{Corresponding address}

\section{Tao Ding, MD}

Department of Orthopaedics, Wuxi People's Hospital Afflicted to Nanjing Medical University 299 Qing yang Road, 214023 Wuxi, Jiangsu Province, China drdingtao@gmail.com

\section{Compliance with ethical guidelines}

Conflict of interest. W. Wang, T. Ding, J.S. Harrop, H. Yang, X. Gu, D. Feng, Y. Zhang, H. Liu, F. Tang, Y. Xue, M. Lu and C. Wu declare that they have no competing interests.

All procedures performed in studies involving human participants were in accordance with the ethical standards of the institutional and/or national research committee and with the 1975 Helsinki declaration and its later amendments or comparable ethical standards. Informed consent was obtained from all individual participants included in the study.

Open Access. This article is distributed under the terms of the Creative Commons Attribution 4.0 International License (http://creativecommons.org/licenses/by/ 4.0/), which permits unrestricted use, distribution, and reproduction in any medium, provided you give appropriate credit to the original author(s) and the source, provide a link to the Creative Commons license, and indicate if changes were made.

\section{References}

1. Matsunaga S, Sakou T (2012) Ossification of the posterior longitudinal ligament of the cervical spine etiology and natural history. Spine 37(5):E309-E314

2. Yamaguchi S, Mitsuhara T, Abiko M, Takeda M, Kurisu K (2018) Epidemiology and overview of the clinical spectrum of degenerative cervical myelopathy. Neurosurg Clin N Am 29(1):1

3. NouriA, TetreaultL, Singh A, Karadimas SK, Fehlings MG (2015) Degenerative cervical myelopathy epidemiology, genetics, and pathogenesis. Spine 40(12):E675-E693

4. Liu XZ, Min SX, Zhang H, Zhou ZL, Wang HH, Jin AM (2014) Anterior corpectomy versus posterior laminoplasty for multilevel cervical myelopathy: a systematic review and meta-analysis. Eur Spine J 23(2):362-372

5. Yoshii T, Sakai K, Hirai T et al (2016) Anterior decompression with fusion versus posterior decompression with fusion for massive cervical ossification of the posterior longitudinal ligament with a $\rangle=50 \%$ canal occupying ratio: a multicenter retrospective study. Spine J 16(11):1351-1357

6. Sun MX, Kong LL, Jiang ZF, Li LM, Lu B (2017) Microscope Enhanced the Efficacy and Safety of Anterior Cervical Surgery for Managing Cervical Ossification of the Posterior Longitudinal Ligament. Med Sci Monit 23:3088-3094

7. Tsuyama N (1984) Ossification of the posterior longitudinal ligament of the spine. Clin Orthop Relat Res 1984(184):71-84

8. Yadav YR, Ratre S, Parihar V, Dubey A, Dubey MN (2018) Endoscopic partial corpectomy using anterior decompression for cervical myelopathy. Neurol India 66(2):444-451

9. Yonenobu K, Abumi K, Nagata K, Taketomi E, Ueyama K (2001) Interobserver and intraobserver reliability of the Japanese Orthopaedic Association scoring system for evaluation of cervical compression myelopathy. Spine 26(17):1890-1894

10. Iwasaki M, Okuda S, Miyauchi A et al (2007) Surgical strategy for cervical myelopathy due to ossification of the posterior longitudinal ligament: Part 2: Advantages of anterior decompression and fusion over laminoplasty. Spine 32(6):654-660

11. Kim B, Yoon DH, Shin HC et al (2015) Surgical outcome and prognostic factors of anterior decompression and fusion forcervical compressive myelopathy due to ossification of the posterior longitudinal ligament. Spine J 15(5):875-884
12. Chen Y, Yang L, Liu Y, Yang H, Wang X, Chen D (2014) Surgical results and prognostic factors of anterior cervical corpectomy and fusion for ossification of the posterior longitudinal ligament. PLOS ONE 9(7):e102008

13. Moon JH, Lee S, Chung $\mathrm{CK}$, Kim CH, Heo W (2017) How to address cerebrospinal fluid leakage following ossification of the posterior longitudinal ligament surgery. JClin Neurosci 45:172-179

14. Liu K, Shi J, Jia L, Yuan W (2013) Surgical technique: Hemilaminectomy and unilateral lateral mass fixation for cervical ossification of the posterio longitudinal ligament. Clin Orthop Relat Res 471(7):2219-2224

15. Tetreault LA, Karpova A, Fehlings MG (2015) Predictors of outcome in patients with degenerative cervical spondylotic myelopathy undergoing surgical treatment: results of a systematic review. Eur Spine J 24:S236-S251

16. Jia J, Chen W, Xu LB, Wu TL, Cheng XG (2017) A modified laminoplasty technique to treat cervical Myelopathy secondary to ossification of the posterior longitudinal ligament (OPLL). Med Sci Monit 23:4855-4864

17. Ohya J, Oshima Y, Oka H et al (2016) Patient satisfaction with posterior decompression surgery for cervical ossification of the posterior longitudinal ligament: prognostic radiographic factors and patient-reported outcomes for the effectiveness of surgical treatment. World Neurosurg 96:272-279

18. HouY, Liang L, ShiGDetal (2017)Comparing effects of cervical anterior approach and laminoplasty in surgical management of cervical ossification of posterior longitudinal ligament by a prospective nonrandomized controlled study. Orthop Traumatol-surg Res 103(5):733-740 